\title{
Political Instability in the Context of Health Security amid COVID-19 Pandemic
}

\author{
Adebisi $\mathrm{YA}^{1,2,3 *}$ \\ ${ }^{1}$ Global Health Focus, Rwanda \\ ${ }^{2}$ Faculty of Pharmacy, University of Ibadan, Nigeria \\ ${ }^{3}$ National Agency for Food and Drug Administration and Control, Nigeria
}

\section{Mini Review}

Volume 5 Issue 4

Received Date: November 22, 2021

Published Date: December 21, 2021

DOI: $10.23880 /$ eij-16000212

*Corresponding author: Yusuff Adebayo Adebisi, Global Health Focus, Kigali, Rwanda, Email: adebisi.adebayo@ghfocus.org

\section{Abstract}

In this article, I discussed the current situation of political instability in Nigeria and Afghanistan amid the COVID-19 pandemic to justify why it is an integral determinant of optimal health security. The COVID-19 pandemic is not just a health emergency, it is a revelation that there is no health security without resilient health systems. Despite the importance of people's social and political environments for health systems resilience, political instability is not often accorded the much-needed attention. In a politically unstable environment, stakeholder's preparedness and responses to health emergencies will be sub-optimal. This implies that health systems strengthening, health emergency preparedness, response to public health emergencies, and health promotion and disease prevention initiatives will be optimized in a stable political climate. No matter the investment made to strengthen the health system of a country, any surge in political instability can have a detrimental impact on health security.

Keywords: COVID-19; Political Instability; Health Security; Nigeria; Afghanistan; Global Health

\section{Introduction}

There is significant confusion surrounding the definitions of political instability [1,2]. In the context of this paper, political instability is defined as "a condition in political systems in which the institutionalized patterns of authority break down, and the expected compliance to political authorities is replaced by political violence" [1]. The breakdown and the resulting political violence can make the government weaker and unable to ensure the security of its people across board, including health. Political violence, which may include guerrilla warfare, banditry, kidnapping, insurgency, terrorism, genocide, rebellion, police brutality, revolution, rioting, and civil war, can be differentiated in different ways, by the nature of the intent, attack targets, the organizational structure of groups and by the repertoire of actions [3]. This explanation gave a broad overview of the concept of political instability and it is widely accepted $[1,2]$. There has also been an elevated attempt to understand the scope and determinants of health security [4]. Despite the importance of people's social and political environments for health security [5], political instability is not often accorded the much-needed attention. While political stability is crucial in economic growth and development, its consequence is almost the same, if not higher on health security. COVID-19, for instance, is already a threat to health security $[6,7]$, and any surge in political instability will contribute to the reversal of any hard-won progress in curbing the outbreak. The pandemic is not just a health emergency, it is a revelation that there is no health security without resilient health systems. No country can protect the health of its populace and achieve the goal of health security in an unstable political climate. According to the Center for Diseases Control and Prevention, health security is "the existence of strong and resilient public health systems that can prevent, detect, and respond to infectious disease threats, wherever they occur in the world" [8]. In a politically unstable environment, stakeholder's preparedness and responses to 


\section{Epidemiology International Journal}

health emergencies will be sub-optimal. Besides, political instability usually leads to the violation of political security that can exacerbate health inequalities. This occurs because of the redirection of attention and resources to curb the instability and further emphasizes that political (in) stability and health security are interconnected and inseparable. In this article, I performed an analysis of the current situation in Nigeria and Afghanistan amid the COVID-19 pandemic to justify why political stability is an integral determinant of health security.

\section{Discussion}

COVID-19 continues to overstretch and strain health systems around the world $[9,10]$. The outbreak serves as one of the major threats facing health security in the 21st century. Before the emergence of the COVID-19 pandemic, many countries including Nigeria and Afghanistan have been facing political instability for many years [11,12]. The political instability across countries has come in different forms which include demonstrations, strikes, and various forms of violence, wars, crimes, coups, regime reversals, banditry, terrorism, and government collapse [1]. In a politically unstable environment, even amid an outbreak, people are more concerned about protecting their lives and properties, expressing their displeasure, agitating for freedoms, or fighting for their rights. In a situation like this, obeying precautionary health measures to curb public health emergencies is the least of the public's priorities.

A deduction from this is that, only when people are safe, feel secured, and in a politically stable climate would the actualization of health security becomes achievable. In other words, saying political stability will strengthen health security would not be untrue. Health systems strengthening, health emergency preparedness, response to public health emergencies, and health promotion and disease prevention initiatives will be optimized in a stable political climate (Figure 1).

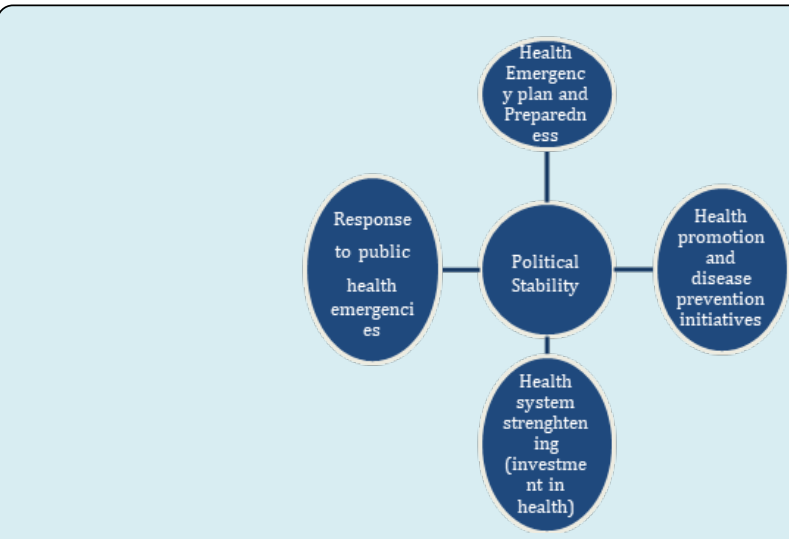

Figure 1: Political stability as a central determinant for health security.

For many years, Nigeria has been facing political instability and several insecurity issues have stemmed from it. The country recorded its first COVID-19 case on 27 February 2020 and since then; insecurity fueled by political instability worsens and has posed a challenge to the containment of the outbreak. In Borno State, the Lake Chad Basin area hardest hit by Boko Haram has recorded one of the highest numbers of confirmed COVID-19 cases and deaths in Northeast Nigeria as of 28 June 2021 [13]. Amid the global pandemic, Nigeria also experienced a nationwide protest in October 2020 to call for a complete ban of the Special Anti-Robbery Squad of the country's police unit due to their nefarious acts [14]. However, the government failed to act swiftly and this led to major protests while the country is battling with the COVID-19 outbreak. Due to the widespread nationwide protests, the country saw a rise in COVID-19 cases in the following weeks after the demonstrations [15].
A report by Dataphyte revealed that insecurity caused over 70,000 deaths in Nigeria between 2012 and 2020 [16]. According to the Council on Foreign Relations, since January 2020, killings by bandits, kidnappers, Fulani herdsmen-farmers clashes, Niger-Delta militants, Boko Haram insurgency, and religious/cultural violence have also claimed many lives in the country [17]. A breakdown of the deaths showed that from January to May 2020 no fewer than 2,771 deaths have been reported due to the instability [17]. A recent report by Global Rights Nigeria revealed that banditry alone claimed 906 lives, which made it the highest cause of killings in the country and followed by Boko Haram attacks claiming 207 lives in Nigeria while kidnapping recorded 1,774 abductees in the first quarter of 2021 [18]. As of September 2021, Zamfara and around seven states in the country's northwest and north-central states have been experiencing attacks on schools and kidnappings by bandits 


\section{Epidemiology International Journal}

[19]. SBM Intelligence's Data shows that between January and November 2020, there were about 140 incidents in the Boko Haram insurgency in northeast Nigeria, an average of 13 a month [20]. A minimum of about 1,600 people was killed in 125 fatal incidents, an average of 13 per incident, suggesting that Nigeria is the third-most terrorized country globally, according to the Global Terrorism Index released in November 2020 [20]. All these instabilities-driven insecurities have negatively affected Nigeria's response to COVID-19 and other outbreaks.
Amidall these crises, violation of COVID-19 precautionary measures is inevitable. For instance, it has been reported that during the protest against police brutality, many protesters did not wear nose masks, and physical distancing was not observed (Figure 2) [14]. The impact of these instabilities on responses to other public health measures has also been reported. This emphasizes the fact that if political instability coexists with public health emergencies, health responses will be negatively impacted and little or no progress would be made towards effective containment.

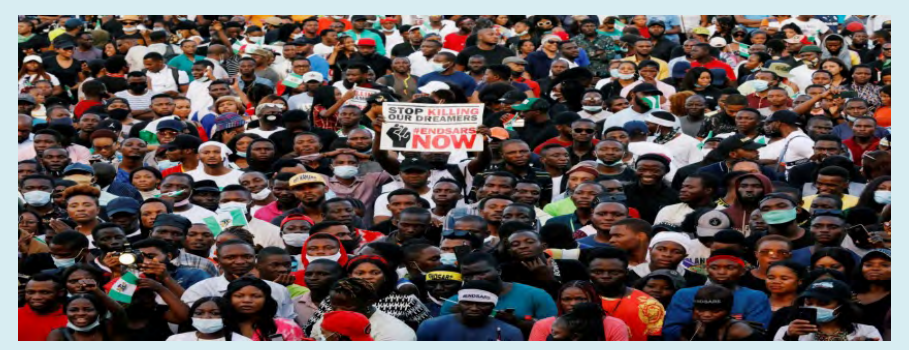

Figure 2: Protesters in Lagos, Nigeria during the EndSARS protest [No Physical Distancing Observed]. Source: Quartz Africa, Recolored for Anonymity.

Many years of political instability, on-going conflict, economic chaos, and drought have also left Afghanistan as one of the most unstable nations in the world [21]. With the emergence of the COVID-19 pandemic, the country now faces another formidable task of containing the outbreak. Afghanistan's health system is already fragile, underresourced, and underfunded and has been ranked low in its capacity to respond to public health emergencies. Amid the COVID-19 pandemic, the country continues to face various political violence, conflicts, and insecurities across different provinces, which further hamper the containment of the outbreak.

In 2020, conflict as a result of political instability in the southern part of the country displaced around 10,000 people [22]. In Nangarhar province, during a funeral, 24 people were killed and many were injured in the early days of the pandemic [23]. This happened a day after 4 civilians were wounded by a bomb explosion in the northern district of Kabul [23]. In March 2020, a Sikh temple in the capital was attacked by a gunman and 25 people died [23]. In the mid-2021 report of the UN Assistance Mission in Afghanistan, they reported that there were more than 1,650 civilians killed and over 3,250 wounded, which is about a $50 \%$ increase compared with the same period in 2020 [24]. In other words, the conflict in the country has claimed more than 5,000 civilian casualties as of June 2021 [24] (Figure 3). The insecurity also increases as the international troops began the departure from the country [24]. There has also been a concern on what the state of the country's security would be as the Taliban takes over power.

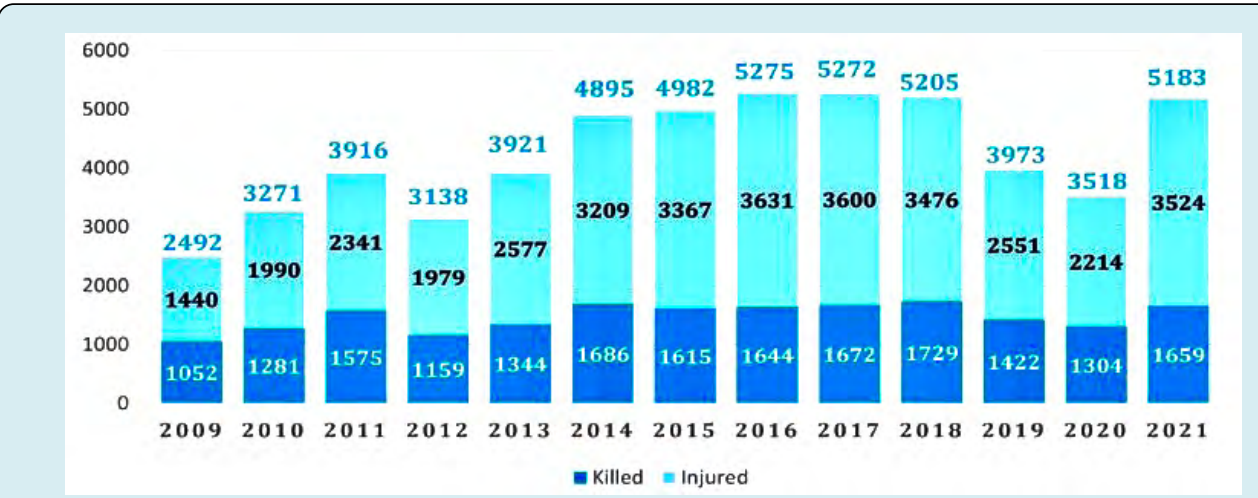

Figure 3: Total civilian causalities from 1 January 2009 to June 2021. Source: UNAMA. 


\section{Epidemiology International Journal}

This situation in Afghanistan amid the global pandemic revealed that health security is the least of the country's priorities amid the persistent political instability. Polio, and other outbreaks have been reported amid the twin epidemic of political instability and the COVID-19 pandemic in the country [25]. This scenario that played out in Afghanistan is a typical example of how political instability can have a gruesome impact on public health responses and preparedness plans for health emergencies. Healthcare workers are also not spared from the outcome of political instability [26]. The insecurity in Nigeria and Afghanistan has led to the death of many health workers [27]. This is worrisome because without sufficient human resources for health, achieving health security is a mirage. The Safeguarding Health in Conflict Coalition identified 43 incidents of violence against or obstruction of health care, 18 health workers kidnapped, and 10 incidents where health commodities are looted in Nigeria in 2020 [28]. According to the same organization, Afghanistan recorded 106 violence against or obstruction of health care, 28 hospital closures, and 19 health workers arrested, and 19 health workers killed in the same year [28]. Violence and conflict against health workers and facilities are a threat to health security.

Based on the situation in Nigeria and Afghanistan, it can be said that political instability can also be a key driver for health inequity. This is because the marginalized and vulnerable communities are disproportionately affected by the outcomes of the instability. The COVID-19 pandemic has also revealed that health systems are not given attention until there is a crisis and this also adds to the reason the impact of political instability is not often considered in preparedness plans for health emergencies. Health equity cannot be achieved without health security in a politically stable climate. Political instability and health crises are also not without their mental health implications and optimal health security is impossible without a proper state of mental health among the public.

It is also worthy to note, if health emergencies are not curbed in a politically unstable country, no other country is truly safe. This calls for global solidarity, partnership, and collaboration more than ever to ensure that no country is left behind. Learning health systems on the impact of political instability on health security for future public health emergencies plans, preparedness and responses remains pertinent.

\section{Conclusion}

Political stability should be seen as a major determinant of health security. With the current state of issues in Nigeria and Afghanistan, I started a discussion on why political stability, health systems strengthening, and health security efforts for prevention, alert, and response need to be pursued in tandem. They must be seen as a mutually reinforcing strategy for developing resilient health systems. No matter the investment made to strengthen the health system of a country, any surge in political instability can have a detrimental impact on health security.

\section{References}

1. Morrison DG, Stevenson HM (1971) Political instability in independent black Africa: more dimensions of conflict behaviour within nations. Journal of Conflict Resolution 15(3): 347-368.

2. Ibeanu $O$ (2021) Political Instability and the Challenge of Democratization in Africa: A Conceptual Analysis. pp: 1-31.

3. Amalu NS (2015) Impact of Boko Haram insurgency on human security in Nigeria. Global Journal of Social Sciences 14(1): 35-42.

4. (2002) Institute of Medicine (US) Committee on Assuring the Health of the Public in the 21st Century. In: The National Academies Press, Washington (DC), USA.

5. Sousa CA (2013) Political violence, collective functioning and health: a review of the literature. Med Confl Surviv 29(3): 169-197.

6. Adebisi YA, Rabe A, Prisno DE (2021) Risk communication and community engagement strategies for COVID-19 in 13 African countries. Health Promot Perspect 11(2): 137-147.

7. Prisno DE, Adebisi YA, Lin X (2020) Current efforts and challenges facing responses to 2019-nCoV in Africa. Glob Health Res Policy 5: 21.

8. (2021) What is Global Health Security?. CDC.

9. Dubey S, Biswas P, Ghosh R, Chatterjee S, Dubey MJ, et al. (2020) Psychosocial impact of COVID-19. Diabetes Metab Syndr 14(5): 779-788.

10. Amos OA, Adebisi YA, Bamisaiye A, Olayemi AH, Ilesanmi $\mathrm{EB}$, et al. (2021) COVID-19 and progress towards achieving universal health coverage in Africa: A case of Nigeria. Int J Health Plann Manage 36(5): 1417-1422.

11. Prisno DE, Essar MY, Ahmadi A, Lin X, Adebisi YA (2020) Conflict and COVID-19: a double burden for Afghanistan's healthcare system. Conflict and Health 14(1): 65.

12. Sofuoğlu E, Ay A (2020) The relationship between climate change and political instability: the case of MENA countries (1985: 01-2016: 12). Environmental Science 


\section{Epidemiology International Journal}

and Pollution Research 27: 14033-14043.

13. Samuel M (2021) Boko Haram and COVID-19: Lake Chad Basin's war on two fronts. ISS Africa.

14. Okereke M, Ogunkola IO, Adebisi YA, Lucero Prisno DE (2021) Dealing with two 'SARS' outbreaks in Nigeria: The public health implications. Public Health Pract (Oxf) 2: 100054 .

15. Ohia C, Salawu MM (2020) COVID-19 pandemic and civil unrests in Africa: implication of recent \#EndSARS protests for increased community transmission in Nigeria. Pan Afr Med J 37(S1): 47.

16. Adeyeye P (2020) At 60: The Changing Face of Insecurity in Nigeria. Dataphyte.

17. Olaiya TT (2020) Killings, kidnappings, banditry hold sway amid COVID-19 pandemic. The Guardian.

18. Ewepu G (2021) Insecurity: Global Rights reports 1,603 Nigerians killed within Q1 of 2021. Vanguard.

19. Kola O (2021) Gunmen kidnap dozens of students in north-western Nigeria. Anadolu Agency.

20. Olurounbi R (2021) Nigeria: Will insecurity, kidnapping and crime get worse in 2021?. The Africa Report.

21. Lucero Prisno DE, Ahmadi A, Essar MY, Lin X, Adebisi YA
(2020) Addressing COVID-19 in Afghanistan: What are the efforts and challenges?. J Glob Health 10(2): 020341.

22. (2020) Afghanistan Strategic Report: No. 64. WHO, pp: $1-4$.

23. (2020) Afghanistan: Deadly suicide attack targets funeral in Nangarhar. Aljazeera.

24. Afghanistan Protection of Civilians in Armed Conflict Midyear Update: 1 January to 30 June 2021. UNAMA, pp: 1-13.

25. Ahmadi A, Essar MY, Lin X, Adebisi YA, Lucero Prisno DE (2020) Polio in Afghanistan: The Current Situation amid COVID-19. Am J Trop Med Hyg 103(4): 1367-1369.

26. Russo G, Pavignani E, Guerreiro CS, Neves C (2017) Can we halt health workforce deterioration in failed states? Insights from Guinea-Bissau on the nature, persistence and evolution of its HRH crisis. Hum Resour Health 15(1): 12.

27. Haar RJ, Read R, Fast L, Blanchet K, Rinaldi S, et al. (2021) Violence against healthcare in conflict: a systematic review of the literature and agenda for future research. Confl Health 15(1): 37.

28. (2020) No respite: Violence against Health Care in Conflict. Safeguard Health in Conflict pp: 1-97. 